\title{
THE BLOOD VOLUME IN PATIENTS WITH ARTERIOVENOUS FISTULAS ${ }^{1}$
}

\author{
By JAMES V. WARREN, DANIEL C. ELKIN, AND JOHN L. NICKERSON
}

\author{
(From the Departments of Medicine and Surgery, Emory University School of Medicine, At- \\ lanta, Georgia; the Vascular Surgery Center, Ashford General Hospital, White \\ Sulphur Springs, West Virginia; and the Department of Physiology, \\ College of Physicians and Surgeons, Columbia University, \\ New York)
}

(Submitted for publication October 21, 1950; accepted, November 20, 1950)

There has been much controversy concerning the changes in blood volume which occur in the presence of arteriovenous fistulas. The large number of vascular injuries treated at Ashford General Hospital during the recent war offered an unusual opportunity to study this problem. This paper reports observations on the blood volume changes in a group of 41 such patients studied before and after operative removal of an arteriovenous fistula.

In 1924 Holman (1) reported his studies on animals with arteriovenous fistulas. He used the brilliant vital red method of blood volume determination, obtaining a single dyed specimen four minutes after the injection of the dye. He found that the blood volume increased in the presence of a fistula. Later he reported similar blood volume studies in patients with arteriovenous fistulas (2, 3 ); in most instances there was a reduction in blood volume following removal of the fistula. In their studies on blood volume Rowntree and Brown (4) included seven patients with arteriovenous fistulas, three of whom had congenital lesions. Although the average blood volume was slightly above the normal value, in only one patient was there a distinctly increased blood volume. Pemberton and Saint (5) reported finding a slightly elevated value in a single patient with a congenital communication between artery and vein. Reid and McGuire (6) expressed doubt regarding the blood volume changes in view of their findings on three patients studied before and after operation. In one patient there was essentially no change in blood volume; in another, a postoperative decline of $600 \mathrm{cc}$; and in the other, a post-

1 The work described in this paper was done under a contract, recommended by the Committee on Medical Research, between the Office of Scientific Research and Development and the Emory University School of Medicine, Atlanta, Georgia. operative drop of $1,000 \mathrm{cc}$. and nine months later, a return to the preoperative volume. In two experimental animals they found that a slight increase in blood volume accompanied the fistula. Using the blue dye T-1824 in a single case, Ellis and Weiss (7) found the blood volume within normal limits, but they did not repeat the measurement postoperatively. Kennedy and Burwell (8) reported a large value in a patient with multiple communications between artery and vein. The volume decreased after operation, but later fluctuated considerably as the fistula recurred.

There are many theoretical and practical objections to the methods used in the earlier studies and more recent observations have been inadequate in number. Therefore, the studies reported here were made.

\section{METHODS}

All determinations reported here were made on patients under basal conditions, at least 12 hours after the last meal and before arising in the morning. The plasma volume was measured using the blue dye T-1824 recommended by Gregersen, Gibson, and Stead (9). All blood samples were taken from the antecubital veins, using a dry syringe, and avoiding the hemoconcentrating effect of a tourniquet. After obtaining a dye-free sample, $3 \mathrm{cc}$. of an 0.1 per cent solution of the dye was injected from a calibrated syringe, and the syringe was rinsed three times with blood. Care was taken to prevent and note any extravascular loss of the dye. Exactly 10 minutes after the dye injection, a dyed sample of blood was obtained, again with precautions against hemolysis and hemoconcentration. In some patients, but not all, an inlying needle was left in place and serial samples obtained in order to determine the rate of disappearance of the blue dye.

The blood samples were placed in small tubes under a layer of mineral oil, allowed to clot and retract, then were centrifuged gently. The samples were discarded if there was evidence of lipemia or hemolysis. A Coleman Junior Spectrophotometer or a Nickerson decade photometer (10) was used in determining the concentration of 
the dye T-1824. This was done by measuring the light absorption of the dyed serum samples relative to the dyefree sample at a wave length of 620 millimicrons. Previously the apparatus had been calibrated with known amounts of dye in serum.

Blood specimens were also obtained for hematocrit reading, hemoglobin, and total protein determinations. Heparin was used as the anticoagulant in the hematocrit tubes. The hemoglobin concentration was determined by measuring the optical density of a dilute alkaline solution of blood. Total protein was determined by the density method of Barbour and Hamilton (11).

The plasma volume was calculated from either the dye concentration value obtained from extrapolation of the disappearance curve plotted semilogarithmically (12), or from the single 10 -minute point as suggested by Gregersen (13). The total blood volume was determined from the plasma volume and the hematocrit reading. To facilitate comparison between patients of different size, the blood volume per square meter of body surface was calculated.

Additional studies, reported in detail elsewhere $(14,15)$, were made on many of these patients. Included were roentgenographic estimations of the heart size (obtained by measuring the transverse diameter of the heart on a teleoroentgenogram), and cardiac output determinations (by the ballistic method).

\section{RESULTS}

Observations were made on 41 patients, and the essential findings are reported in Table I. All patients had arteriovenous fistulas resulting from trauma. As far as could be determined, all the patients were healthy young adults before injury, and none had complicating injuries or illness that might have altered the blood volume. There was one woman in the group. Table I shows that the location of the lesions varied considerably. In all patients there were characteristic physical signs of the fistula. The duration between removal of the fistula and the infliction of the wound which caused it varied from slightly more than two months to two years. In no patient was there evidence of frank cardiac failure. The operative removal of the fistula was done with either sodium pentothal or continuous spinal anesthesia. In all instances the fistula was successfully removed, and the postoperative course was uneventful. With the exception of those determinations done on the third postoperative day, the patients were usually allowed out of bed by the time the blood volume determinations were made.

In the entire group, before operation the blood volume per square meter of body surface ranged from $2,400 \mathrm{cc}$. to $4,030 \mathrm{cc}$. Ten days or more after operation it ranged from $2,330 \mathrm{cc}$. to $3,380 \mathrm{cc}$. In 23 patients ( 56 per cent) the change was less than $200 \mathrm{cc}$. A change of $200 \mathrm{cc}$. or less was not considered a significant change.

TABLE I

Summary of observations on 41 patients with arteriovenous fistulas

\begin{tabular}{|c|c|c|c|c|c|c|c|c|}
\hline $\begin{array}{l}\text { Location of fistula } \\
\text { and number of } \\
\text { patients in group }\end{array}$ & $\begin{array}{l}\text { Duration of } \\
\text { fistula }\end{array}$ & $\begin{array}{c}\text { Time of } \\
\text { observation }\end{array}$ & $\begin{array}{l}\text { Plasma } \\
\text { volume }\end{array}$ & $\begin{array}{l}\text { Total blood } \\
\text { volume }\end{array}$ & $\begin{array}{c}\text { Deviation } \\
\text { from normal } \\
\text { blood volume }\end{array}$ & $\begin{array}{l}\text { Hematocrit } \\
\text { reading }\end{array}$ & $\begin{array}{l}\text { Total plasma } \\
\text { protein }\end{array}$ & Heart size \\
\hline $\begin{array}{l}\text { Carotid } \\
(1)\end{array}$ & $\begin{array}{c}\text { months } \\
3.5\end{array}$ & $\begin{array}{c}\text { days before and } \\
\text { after operation } \\
1 \text { before } \\
21 \text { after }\end{array}$ & $\begin{array}{l}c c . \\
2650 \\
2420\end{array}$ & $\begin{array}{c}c c . \\
5100 \\
4385\end{array}$ & $\begin{array}{c}\text { ce. per sq. } m \text {. } \\
-440\end{array}$ & $\begin{array}{l}48.2 \\
44.8\end{array}$ & $\begin{array}{c}\text { ems. per } \\
100 \text { cc. } \\
6.7 \\
6.1\end{array}$ & $\begin{array}{l}c m . \\
-1.5\end{array}$ \\
\hline $\begin{array}{l}\text { Subclavian } \\
(4)\end{array}$ & 3.5 & $\begin{array}{l}7 \text { before } \\
12 \text { after }\end{array}$ & $\begin{array}{l}2848 \\
2932\end{array}$ & $\begin{array}{l}\mathbf{5 5 4 0} \\
\mathbf{5 3 8 7}\end{array}$ & -168 & $\begin{array}{l}49.1 \\
46.1\end{array}$ & $\begin{array}{l}6.0 \\
6.4\end{array}$ & +0.5 \\
\hline$\underset{(5)}{\text { Axillary }}$ & 8.1 & $\begin{array}{l}12 \text { before } \\
20 \text { after }\end{array}$ & $\begin{array}{l}2990 \\
2806\end{array}$ & $\begin{array}{l}5700 \\
4947\end{array}$ & -122 & $\begin{array}{l}47.7 \\
46.8\end{array}$ & $\begin{array}{l}6.3 \\
6.4\end{array}$ & -5.6 \\
\hline $\begin{array}{l}\text { Brachial } \\
\text { (3) }\end{array}$ & 3.5 & $\begin{array}{l}6 \text { before } \\
10 \text { after }\end{array}$ & $\begin{array}{l}2620 \\
2970\end{array}$ & $\begin{array}{l}5053 \\
5220\end{array}$ & 90 & $\begin{array}{l}47.8 \\
49.4\end{array}$ & $\begin{array}{l}6.4 \\
6.5\end{array}$ & 0 \\
\hline $\begin{array}{l}\text { Iliac } \\
(4)\end{array}$ & 6 & $\begin{array}{l}14 \text { before } \\
14 \text { after }\end{array}$ & $\begin{array}{l}3146 \\
2667\end{array}$ & $\begin{array}{l}5616 \\
4957\end{array}$ & -365 & $\begin{array}{l}44.3 \\
46.4\end{array}$ & $\begin{array}{l}6.9 \\
6.3\end{array}$ & -0.6 \\
\hline$\underset{(13)}{\text { Femoral }}$ & 6.1 & $\begin{array}{l}6 \text { before } \\
14 \text { after }\end{array}$ & $\begin{array}{l}2972 \\
2618\end{array}$ & $\begin{array}{l}5645 \\
5169\end{array}$ & -238 & $\begin{array}{l}47.6 \\
49.4\end{array}$ & $\begin{array}{l}6.2 \\
6.4\end{array}$ & -1.2 \\
\hline Popliteal & 6.8 & $\begin{array}{l}7 \text { before } \\
15 \text { after }\end{array}$ & $\begin{array}{l}2827 \\
2856\end{array}$ & $\begin{array}{l}5584 \\
5476\end{array}$ & -76 & $\begin{array}{l}49.2 \\
47.7\end{array}$ & $\begin{array}{l}6.4 \\
6.8\end{array}$ & -0.2 \\
\hline $\begin{array}{c}\text { Tibial } \\
\text { (6) }\end{array}$ & 8.7 & $\begin{array}{l}3 \text { before } \\
19 \text { after }\end{array}$ & $\begin{array}{l}2735 \\
2661\end{array}$ & $\begin{array}{l}5068 \\
4865\end{array}$ & -116 & $\begin{array}{l}45.6 \\
45.0\end{array}$ & $\begin{array}{l}6.2 \\
6.5\end{array}$ & -0.4 \\
\hline
\end{tabular}


In 18 patients ( 44 per cent), after removal of the fistula there was a decrease in blood volume from $200 \mathrm{cc}$. to $1,060 \mathrm{cc}$. per square meter body surface. In many instances these changes were confirmed by repeated observations. On the other hand, in none of the patients was there a significant increase in blood volume following operation.

The hematocrit readings varied slightly, most often showing a tendency to fall somewhat after operation. Therefore, the calculated red blood cell volume underwent similar changes. The hemoglobin and total protein concentration did not undergo marked alteration. The cardiac output data and changes in heart size have been described in detail elsewhere (14).

There has been wide use of the blue dye T-1824 (9) in the determination of plasma volume. In the present studies the disappearance of the dye was plotted semilogarithmically as recommended by Gregersen and Rawson (12). More recently Gregersen (13) has suggested that in certain situations a single dyed specimen obtained 10 minutes after dye injection is almost as reliable as an extrapolated value for dye concentration obtained from the disappearance curve of the dye. He found this true in normal patients and patients in shock. In the case of many patients reported here there were obtained both 10-minute samples and multiple specimens for plotting the disappearance slope of the dye. There was no evidence that the disappearance rate of the dye was affected by the presence of the arteriovenous fistula, and the plasma volume as calculated by the two methods did not differ significantly. It must be remembered, however, that none of these patients had frank congestive heart failure. It is possible that the prolonged mixing time of cardiac failure might invalidate the 10-minute point method. Because of the limited time that the patients were available, and because multiple determinations were made on a large group, the 10 -minute point method was used extensively.

The calculation of the total blood volume from the hematocrit reading and the plasma has been subject to criticism $(16,17)$. This is primarily because the peripheral venous hematocrit reading is imperfect from the standpoint of indicating the proportion of cells in the blood in flow, and because the plasma trapped among the cells in centrifugation prevents arrival at a true cell-plasma ratio by hematocrit reading. Despite the handicaps, a value determined by this means may serve many useful purposes. It appears particularly useful in measurements, such as these reported here, where comparative observations are made on the same person who has minimal hematocrit changes.

Because it appears to be at the expense of the ratio of cells to plasma that the body maintains the total blood volume at a constant level, we found the total blood volume the most stable and useful value for these studies. Since the body can mobilize fluid and protein with relative rapidity, the plasma volume appears to vary to compensate for changes in the red cell volume. Studies on the effect of simple hemorrhage show that these changes in plasma volume first occur with a slow readjustment of the red cell volume and hematocrit reading to the normal value (18). Similar changes may be seen soon after an operation, with its accompanying blood loss and dehydration. Because of this, the plasma volume is subject to much more fluctuation than is the total blood volume, and knowledge concerning it was of less value in these studies than was evidence of changes in the total blood volume. Although some of the postoperative measurements reported here were made relatively early following operation, an effort was made to delay them long enough to avoid any immediate effects of the operation. Only observations made 10 days or more after operation were used in the calculation of the normal values. Almost all of the patients were ambulatory by this time. The values obtained fell in the same range as those reported previously for normal male subjects, the average blood volume being near 2,800 cc. per square meter of body surface (19).

The results of these studies are expressed graphically in Figure 1, considering the postoperative blood volume as the normal for each patient. A majority of the patients showed a change of less than 200 cc. in blood volume per square meter body surface. This degree of change (about 7 per cent of the normal value) may be expected independently, without direct effect on the arteriovenous fistula. Such factors as technical errors in blood volume determination, changes resulting from operation, and bed rest could readily account for a 7 per cent variation. On the other hand, following operation, although no patient had an in- 


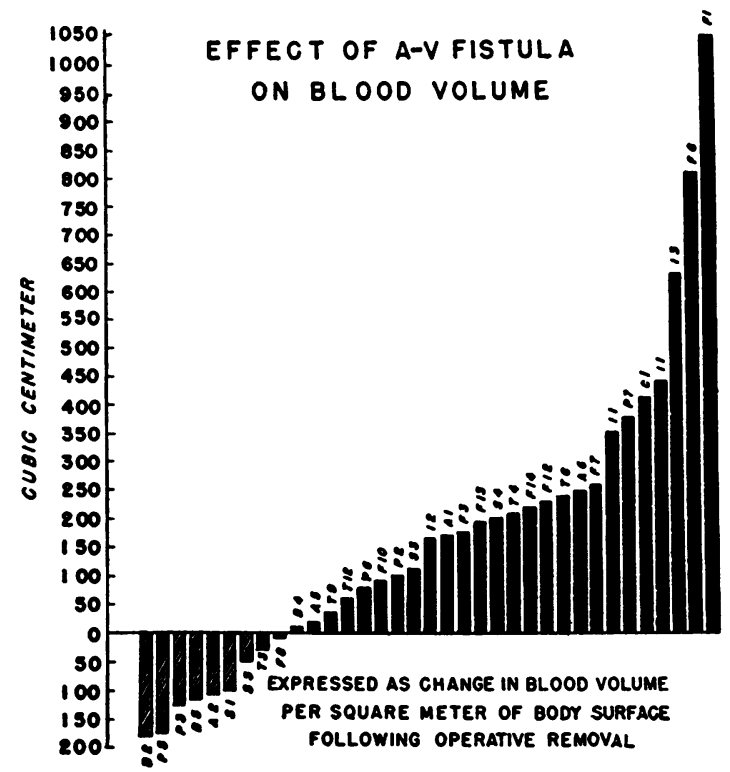

Fig. 1. Effects of an A-V Fistula on Blood Volume

The change in blood volume from before operation to the postoperative period is expressed in cubic centimeters per square meter of body surface.

crease in blood volume greater than $200 \mathrm{cc}$., 18 patients ( 44 per cent) had a decrease of more than $200 \mathrm{cc}$. Insofar as could be determined, this decrease was not related to any technical errors or to any incident of the operation or convalescence not directly related to the removal of the arteriovenous fistula. In several instances repeated ob- servations before and after operation verified the presence of the change, and revealed that the decline was in progress by three days postoperatively, and was apparently complete by 10 days. Observations were not made earlier than three days postoperatively because it was felt that changes incident to the operation might cause alterations in blood volume not due to the actual removal of the fistula.

The findings reported here are in agreement with earlier reports that blood volume may be significantly elevated in patients with arteriovenous fistulas. It is not a consistent reaction, however, as changes were noted in only less than half of the patients studied. In an attempt to elucidate the cause of this blood volume change, an effort was made to relate the blood volume change with other alterations in the circulation.

It appears that the size of the fistula is a major factor in determining the increase in blood volume. For instance, two of the four patients with the greatest change in blood volume had fistulas involving the iliac vessels. However, the actual size of a fistula is difficult to determine. Clinical evidences, such as the size of the vessels involved and the intensity of the thrill or murmur, give some evidence, although not entirely accurate, regarding the magnitude of the shunt. Actual measurement of the fistulous opening upon operation has not proved successful because of the variable de-

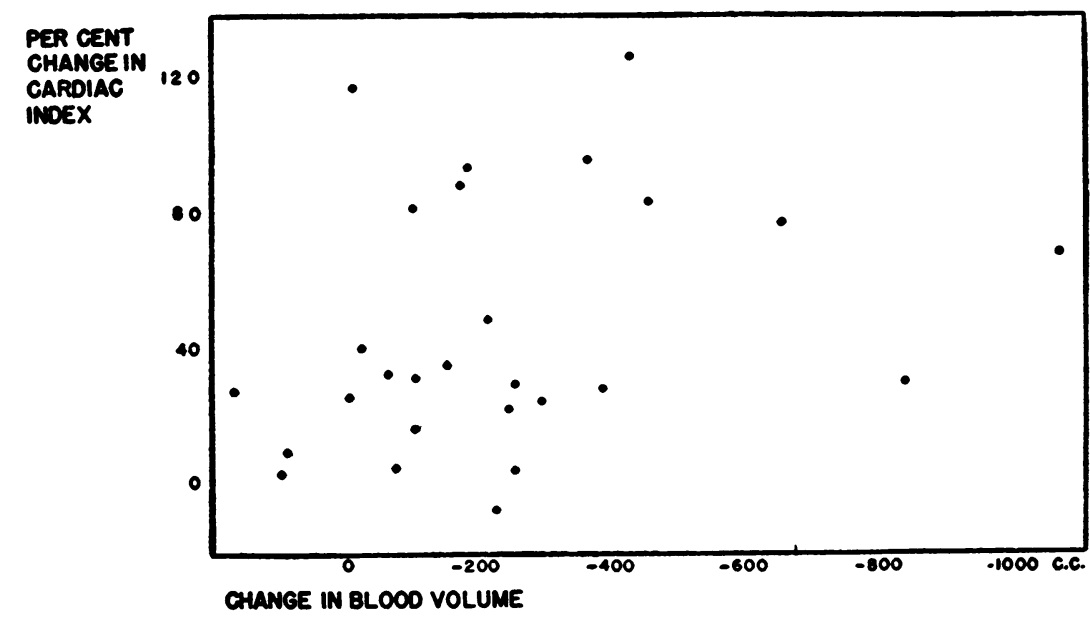

Fig. 2. A Chart Demonstrating the Relationship Between the Change in Cardiac Output and the Change in Blood Volume Following Removal of AN A-V Fistula

The change in blood volume is expressed in cubic centimeters per square meter of body surface. 
gree of vascular spasm. Measurement of the opening after removal from the body is difficult for the same reason plus the shrinking effect of tissue fixation.

In many patients with arteriovenous fistulas the resting level of cardiac output is above normal (14). Since the elevation of the cardiac output above normal might be proportional to the size of the fistula, correlation of the increase in blood volume with the increase in cardiac output was attempted (Figure 2). To avoid the considerable range in basal cardiac output from person to person, the blood volume change was plotted against the per cent of deviation from normal of the cardiac output in the particular patient observed. In other words, if the preoperative cardiac output was twice that found as the postoperative basal value, a 100 per cent increase in cardiac output was plotted. The correlation coefficient was 0.26 , a value which indicated that the correlation was not good. It appears, however, that the size of the fistula may be at least one of several factors in the changes leading to an increased blood volume.

It has repeatedly been observed that in patients with arteriovenous fistulas the heart size, determined roentgenologically, may become abnormally large, and after the fistula is removed, it returns to normal size (20). Since there is evidence to suggest that the heart size is related to the blood volume, these two findings were correlated.
Twenty-nine of the patients had satisfactory teleoroentgenograms of the heart made before and after operation. In many instances there were repeated observations. The change of blood volume was plotted against the change in the transverse diameter of the heart in Figure 3. The correlation coefficient of value 0.36 indicates that a significant degree of correlation was not present. This is not entirely surprising in view of recent evidence that in normal subjects the rapid increase in blood volume of about $1,000 \mathrm{cc}$. failed to produce a distinct change in heart size (21). Holman found a change in heart size in dogs upon increasing or decreasing the blood volume, but he studied changes of much greater magnitude than seen in patients with arteriovenous fistulas (1). A change of $500 \mathrm{cc}$. in a dog such as he studied is equivalent to a change of approximately $4,000 \mathrm{cc}$. in a human. In neither of the afore-mentioned studies was the increase in blood volume accompanied by an increase in extracellular fluid volume, which if present might alter the situation considerably. It appears likely that other factors, such as the increased demand on the heart, play a major role.

An attempt was made to relate the increase in blood volume to the duration of the fistula. Our data are not satisfactory for this purpose, however, because so few patients had large fistulas of long duration. Most of the patients with lesions of con-

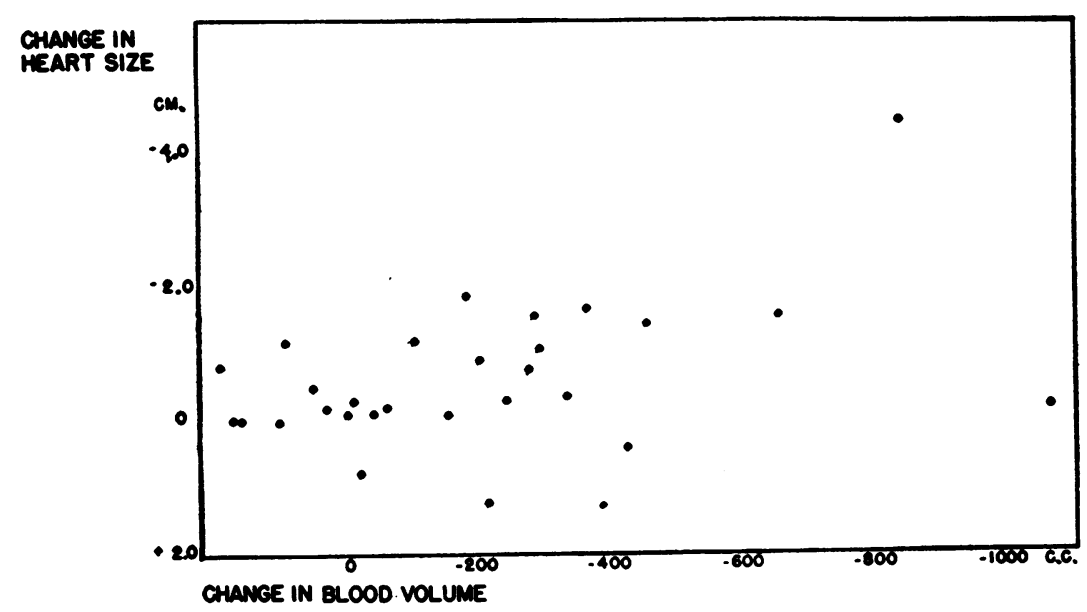

Fig. 3. The Change in Blood Volume Plotted Against the Change in Heart Srze

The change in heart size is expressed as the change in transverse diameter of the heart determined from the teleoroentgenogram. 
siderable age had rather small fistulas which had often escaped notice by the patient and physician.

Our results demonstrate that in some patients with arteriovenous fistulas there is a significant increase in blood volume. After operative removal of the fistula, the blood volume, if elevated, returns to normal. Since the basic factors controlling blood volume in the normal person are so little understood, it is not surprising that we cannot explain the increased blood volume in these patients.

It is possible that with some large venous channels engorged with blood, the mechanisms controlling the blood volume might be misled. Since the amount of blood remaining in the rest of the vascular bed would be less than normal, increased production of blood might be stimulated. This could be the basic mechanism causing the increased blood volume. There is also the possibility that the increased venous pressure in the region of the fistula may dilate the vascular bed in that region, thus increasing its capacity for blood and spurring the demand for more blood.

It has been suggested that the increase in blood volume seen in patients with arteriovenous fistulas merely represents the increase in blood volume seen in patients with any type of congestive heart failure (6) ; that is, it may be the increase in blood volume of cardiac failure rather than that of arteriovenous fistula per se. Although none of the patients observed in these studies developed the complete clinical picture of cardiac failure, it cannot be denied that there may be a similar mechanism in the causation of their increased blood volume.

\section{SUMMARY AND CONCLUSIONS}

1. Observations on the blood volume have been made before and after operative removal of an arteriovenous fistula in 41 patients.

2. In 56 per cent of the patients there were changes in blood volume of less than $200 \mathrm{cc}$. per square meter of body surface. This was not considered a significant variation.

3. In 44 per cent of the patients the decrease in blood volume after operation ranged from $200 \mathrm{cc}$. to $1,060 \mathrm{cc}$. per square meter of body surface, indicating an abnormally large blood volume in the presence of the fistula.
4. The relationship of the change in blood volume to the size and duration of the fistula, the cardiac output, and the changes in heart size have been studied. In general, the patients with an elevated blood volume were those with clinical evidences of a functionally large fistula.

Miss Maurine Giese and Miss Mary Margaret Steele gave valuable technical assistance.

\section{REFERENCES}

1. Holman, E., Experimental studies in arteriovenous fistulas. I. Blood volume variations. Arch. Surg., 1924, 9, 822.

2. Holman, E., Arteriovenous Aneurysm; Abnormal Communications Between the Arterial and Venous Circulations. Macmillan Co., New York, 1937.

3. Holman, E., Clinical and experimental observations on arteriovenous fistulae. Ann. Surg., 1940, 112, 840.

4. Rowntree, L. G., and Brown, G. E., The Volume of the Blood and Plasma, in Health and Disease. W. B. Saunders Co., Philadelphia, 1929.

5. Pemberton, J. de J., and Saint, J. H., Congenital arteriovenous communications. Surg., Gynec. \& Obst., 1928, 46, 470.

6. Reid, M. R., and McGuire, J., Arteriovenous aneurysms. Ann. Surg., 1938, 108, 643.

7. Ellis, L. B., and Weiss, S., The local and systemic effects of arteriovenous fistula on the circulation in man. Am. Heart J., 1929, 5, 635.

8. Kennedy, J. A., and Burwell, C. S., Measurements of the circulation in a patient with multiple arteriovenous connections. Am. Heart J., 1944, 28, 133.

9. Gregersen, M. I., Gibson, J. G., 2nd, and Stead, E. A., Jr., Plasma volume determination with dyes: errors in colorimetry; use of the blue dye $\mathrm{T}-1824$. Am. J. Physiol., 1935, 113, 54.

10. Nickerson, J. L., A portable decade photometer for the determination of blood volume with the dye T-1824. Rev. Scient. Instruments, 1944, 15, 69.

11. Barbour, H. G., and Hamilton, W. F., Blood specific gravity; its significance and a new method for its determination. Am. J. Physiol., 1924, 69, 654.

12. Gregersen, M. I., and Rawson, R. A., The disappearance of T-1824 and structurally related dyes from the blood stream. Am. J. Physiol., 1943, 138, 698.

13. Gregersen, M. I., A practical method for the determination of blood volume with the dye T-1824. J. Lab. \& Clin. Med., 1944, 29, 1266.

14. Warren, J. V., Nickerson, J. L., and Elkin, D. C., The cardiac output in patients with arteriovenous fistulas. J. Clin. Invest., 1951, 30, 210.

15. Nickerson, J. L., Elkin, D. C., and Warren, J. V., The effect of temporary occlusion of arteriovenous fistulas on heart rate, stroke volume, and cardiac output. J. Clin. Invest., 1951, 30, 215.

16. Stead, E. A., Jr., and Ebert, R. V., Relationship of 
the plasma volume and the cell plasma ratio to the total red cell volume. Am. J. Physiol., 1941, 132, 411.

17. Hahn, P. F., Ross, J. F., Bale, W. F., Balfour, W. M., and Whipple, G. H., Red cell and plasma volumes (circulating and total) as determined by radio iron and by dye. J. Exper. Med., 1942, 75, 221.

18. Ebert, R. V., Stead, E. A., Jr., and Gibson, J. G., 2nd, Response of normal subjects to acute blood loss with special reference to mechanism of restoration of blood volume. Arch. Int. Med., 1941, 68, 578.

19. Gibson, J. G., 2nd, and Evans, W. A., Jr., Clinical studies of the blood volume. II. The relation of plasma and total blood volume to venous pressure, blood velocity rate, physical measurements, age and sex in 90 normal humans. J. Clin. Invest., 1937, 16, 317.

20. Pendergrass, R. C., Cardiac changes in arteriovenous fistula. Am. J. Roentgenol., 1945, 53, 423.

21. Warren, J. V., Brannon, E. S., Weens, H. S., and Stead, E. A., Jr., Effect of increasing the blood volume and right atrial pressure on the circulation of normal subjects by intravenous infusions. Am. J. Med., 1948, 4, 193. 